\title{
Relationships Between the Older Adult's Cognitive Decline and Quality of Life: The Mediating Role of the Assistive Mobile Health Applications
}

\author{
https://doi.org/10.3991/ijim.v13i10.11288 \\ Murtaja Ali Saare ${ }^{(凶)}$, Azham Hussain \\ Universiti Utara Malaysia, Kedah, Malaysia \\ alisaare23@yahoo.com \\ Wong Seng Yue \\ Universiti Malaya, Kuala Lumpur, Malaysia
}

\begin{abstract}
This article examines the link between the older adult's cognitive decline, and Assistive Mobile Health Applications in terms of quality of life as researcher has found scarcity in explaining the mediating role of assistive mobile health applications towards the quality of life of older adults with cognitive decline. Researchers have identified the importance of using assistive mobile health applications in connection of the older adult's cognitive decline. However, it remained unaddressed in the explaining the mediating role of assistive mobile health application. Therefore, this paper aims to provide an insight that the adoption of assistive $\mathrm{m}$-health applications will provide this population with potential solution to their challenging aging life, hence, enhancing their quality of life. In addition, this paper is only a conceptual explanation, as it aims to identify the possible reasons that influence their Smartphone adoption. Factors were identified using a systematic literature review on relevant peer reviewed papers. The study summarized the empirical evidences which were used to support the conceptual explanation. It is expected that this work will lead towards the empirical findings on the explanation of the mediating role of the assistive mobile health applications to address the relationship of older adult's cognitive decline and quality of life. This paper provides directions for future studies in improving the quality of life of older adults.
\end{abstract}

Keywords - Assistive mobile health applications, cognitive decline, older adults, quality of life

\section{Introduction}

Technological development has increased the average life expectancy as a result of improved public health (Bujnowska-Fedak \& Pirogowicz, 2014) which is evident as there is an increase in world aging population. This rapid increase in number of people living longer has led the researcher's interest in the improvement of quality of life of older age internationally. For example, in 2012, 43.1 million adults, which is $13.7 \%$ of 
the US population, which age 65 years or old. By 2050 that number is expected to grow to 83.7 million, or a quarter of the US population (Crouch, Probst, \& Bennett, 2017; Hinrichsen, Emery-Tiburcio, Gooblar, \& Molinari, 2018; Ortman, Velkoff, \& Hogan, 2014). A similar pattern has been revealed with $39 \%$ increase in number of older adults in England (Holliday, Ward, \& Awang, 2016). Moreover, 5 million in 2011 which is expected to be doubled in the next 25 years in Canada (Canada, 2014; McKinnon, Connelly, Rice, Hunter, \& Doherty, 2017), The World Health Organization estimates that by the year 2020, 24\% of Europeans, $17 \%$ of Asians, and $23 \%$ of North Americans will be over the age of 60 . It is expected that by 2020 there will be more than 1 billion people age 60 and over (Chadwick-Dias, Tedesco, \& Tullis, 2004).

Increase in age brings increased likelihood of illness. As elderly population are easily infected by diseases such as high blood pressure, heart problems, overweight, and diabetes etc. Centers for Disease Control and Prevention (CDC) found that 30.3 million people have diabetes. Diabetes has been found as one of the primary cause of premature death worldwide and it is predicted that there will be rise in death rate as previously $30 \%$ of patients die within 1 year, $50 \%$ die within 3 years and $70 \%$ die within last 5 years (Apelqvist, 2018).

Diabetes is one of such diseases which must be monitored regularly for balancing the blood glucose levels in the body which is difficult for older adult to visit a medical specialist daily, as older adults are depend and require support and visiting a clinic requires high cost (Holliday, Ward, \& Fielden, 2015). Therefore, in order to overcome high cost of health (Jones \& Rowbottom, 2010), supporting independence (Pinkelman, Roll, \& Greene, 2016) and improving the wellbeing (Holliday et al., 2015), technology plays a significant role and provide solutions for the needs of older adults(Czaja \& Lee, 2009; Thilo, Bilger, Halfens, Schols, \& Hahn, 2017)such as mobile health care (Chou, Chang, Lee, Chou, \& Mills, 2013; Miller, Cafazzo, \& Seto, 2016; Stellefson et al., 2017). However, not all age groups are accepting and using Smartphone. For example, only $18 \%$ of older adults has adopted to Smartphone (M. Anderson \& Perrin, 2017; Saare, Ta, Lashari, \& Sari, 2018; A. Smith, 2014). The possible reasons for not adopting these Smartphone has been revealed by literature as gap in understanding the significant differences in terms of requirements of user-interface design (Poushter, 2016). The present Smartphone interface are complex and are developed based on the needs of younger adults which affect their adoption process for older adults (Petrovčič, Taipale, Rogelj, \& Dolničar, 2018).

The interface requirements of older adults are different from younger adults (Joshi \& Bråthen, 2016) due to decline in cognition with age (Chin et al., 2017). Cognition refers to the thinking pattern and in older adults it has been declined due to age which affect the information processing capacity (Thow et al., 2018). For example, complex menu structures causes older adults to experience stress as it require older adults to think for a longer time out what to select (Gao, Ebert, Chen, \& Ding, 2015; Petrovčič, Taipale, et al., 2018). Moreover, previous studiespoorly captured the specific requirements of older adults. Hence, they did not meet their needs (Young, Koppel, \& Charlton, 2016) and existing smartphone interface are based on suitability of younger adults who do not have cognitive decline (Azir Rezha, Maksom, \& Naim, 2014). Hence, there is a gap in literature in understanding the smartphone adoption by older adults. 
Smartphone applications are beneficial as they can provide health services that can monitor health, as it provides interactive health services to patients, clinicians and caregivers for the self-management of predicted diseases (Holliday et al., 2015) and support self-management of chronic diseases (Hu et al., 2018) such as diabetes. Moreover, smartphone application (Saare, Ta'a, Lashari, \& Sari, 2018) are low cost, thus, help older adults by providing an opportunity to alleviate the burden of primary health care of older adults (Elshourbagy, 2017) and promote healthy lifestyle. As smartphone applications especially healthcare applications(Saare, Murtaja Ali; Jasim, Osamah Mohammed; Mahdi, Alia Ahmed; Hussain, 2018) designs are skewed towards younger adults (Grindrod et al., 2018; Kuerbis, Mulliken, Muench, Moore, \& Gardner, 2017; Petrovčič, Taipale, et al., 2018; Tsai, Shillair, \& Cotten, 2017) and there are today's technological products are not designed for older adults (Liu \& Joines, 2012).But it is known that diabetes is common in the elderly population (Meneilly \& Tessier, 2001). However, the success of any type of application depends on how well it is being used by the user i.e. the usability and how well it is suited to the user's requirements based on their experience (Kalimullah \& Sushmitha, 2017). Therefore, the design of these applications should be favorable for older adult population to offer promising healthcare and wellness management applications. Thus, the present study is providing a framework which would systematically combine user characteristics such as diabetes and cognitive decline. Hence, providing a holistic view of older adult's low level of smartphone adoption by identifying the factors that are affecting the smartphone applications adoption and proposing a conceptual framework from an older adult perspective to improve quality of life (Petrovčič, Taipale, et al., 2018).This framework would provide guidance for usability specialists, product designers, interaction designers, product manufacturers and others involved in the design and development of user interfaces when seeking an ultimate design solution to support quality of life of older adults using assistive mobile health application(Liu \& Joines, 2012).

\section{$2 \quad$ Methodology}

Previous literature was reviewed using a Top down (review of the literature) approach to develop a conceptual framework which involved keeping in mind the barriers in the adoption of mobile health application to enhance the quality of life of older adults with cognitive decline. Literature search and database selection.

The first step used to search the literature consisted of choosing database IEEE Xplore, Science Citation Index, Scopus, Science Direct, Science Citation Index, and Web of Science. Database was searched using keywords related to the concepts of assistive mobile health technology, older adults, diabetes, and quality of life. 
Table 1. Previous studies on assistive technologies for healthcare in older adults

\begin{tabular}{|c|c|c|c|c|c|c|c|c|c|}
\hline & $\begin{array}{c}\text { (Me- } \\
\text { neilly } \\
\text { \&Tessier } \\
\text {, 2001) }\end{array}$ & $\begin{array}{l}\text { (Broekens } \\
\text {, Heerink, } \\
\text { \& Rosen- } \\
\text { dal, 2009) }\end{array}$ & $\begin{array}{c}\text { (Broad- } \\
\text { bent,Staf- } \\
\text { ford,\&Mac } \\
\text { Donald, } \\
\text { 2009) }\end{array}$ & \begin{tabular}{|c|} 
(Zwijsen,Nie \\
meijer,\& \\
Hertogh, \\
2011)
\end{tabular} & $\begin{array}{c}\text { (Gar } \\
\text { cía- } \\
\text { Casa } \\
1 \text { et } \\
\text { al.., } \\
2017 \\
)\end{array}$ & \begin{tabular}{|c|} 
(Pinto- \\
Bruno, Gar- \\
cía-Casal, \\
Csipke, Je- \\
naro- \\
Río,\&Franco \\
-Martín, \\
2017) \\
\end{tabular} & $\begin{array}{c}\text { (D.Smit } \\
\text { h et al., } \\
2017 \text { ) }\end{array}$ & \begin{tabular}{|c|} 
(Müller, \\
Lauten- \\
schlä- \\
ger, \\
Meyer, \\
\& \\
Stephan \\
, 2017)
\end{tabular} & $\begin{array}{c}\text { (Mouss } \\
\text { a et al., } \\
\text { 2017) } \\
\\
\\
\end{array}$ \\
\hline $\begin{array}{l}\text { Number } \\
\text { reviewed } \\
\text { papers }\end{array}$ & 18 & 43 & 11 & 46 & 37 & 6 & 15 & 5 & 3 \\
\hline $\begin{array}{l}\text { Number } \\
\text { of } \\
\text { searched } \\
\text { data- } \\
\text { bases }\end{array}$ & 2 & 3 & 3 & 11 & 12 & 4 & 5 & 6 & 3 \\
\hline \begin{tabular}{|l|} 
Year of \\
Publica- \\
tion \\
for the \\
searched \\
papers \\
\end{tabular} & $\begin{array}{l}2001- \\
2016\end{array}$ & $2000-2007$ & Till 2008 & Till 2009 & $\begin{array}{c}2006 \\
- \\
2014\end{array}$ & Till Jan 2016 & \begin{tabular}{|c}
1 Janu- \\
ary \\
$1949-31$ \\
Decem- \\
ber 2015
\end{tabular} & $\begin{array}{l}\text { Till July } \\
15,2015 \\
\end{array}$ & $\begin{array}{c}\text { Till } \\
2015\end{array}$ \\
\hline \begin{tabular}{|l|} 
Hasadop \\
tion \\
concept \\
been \\
consid- \\
ered?
\end{tabular} & No & $\begin{array}{c}\text { Yes, Inter- } \\
\text { face el- } \\
\text { derly and } \\
\text { Quality } \\
\text { of life }\end{array}$ & $\begin{array}{c}\text { Yes, quality } \\
\text { of life, and } \\
\text { user satis- } \\
\text { faction }\end{array}$ & $\begin{array}{c}\text { Yes, Assis- } \\
\text { tive technol- } \\
\text { ogy and qual- } \\
\text { ity of life }\end{array}$ & $\begin{array}{c}\text { Yes, } \\
\text { fac- } \\
\text { tor } \\
\text { com- } \\
\text { puter } \\
\text { use } \\
\text { over } \\
\text { cog- } \\
\text { nitive } \\
\text { de- } \\
\text { cline } \\
\end{array}$ & \begin{tabular}{|c|} 
Yes, techno- \\
logical solu- \\
tions to im- \\
prove and fa- \\
cilitate social \\
health and so- \\
cial participa- \\
tion and qual- \\
ity of life of \\
older adults \\
living \\
\end{tabular} & \begin{tabular}{|c} 
Yes, a \\
factor \\
predict- \\
ing med- \\
ication
\end{tabular} & \begin{tabular}{|c|} 
Improv- \\
ing \\
health \\
related \\
quality \\
of life of \\
people
\end{tabular} & $\begin{array}{l}\text { Mobile } \\
\text { health } \\
\text { technol- } \\
\text { ogy and } \\
\text { patients }\end{array}$ \\
\hline $\begin{array}{l}\text { Have } \\
\text { Theories } \\
\text { been } \\
\text { identi- } \\
\text { fied? }\end{array}$ & No & No & No & $\begin{array}{c}\text { Political the- } \\
\text { ory }\end{array}$ & No & No & No & $\begin{array}{c}\text { Theory } \\
\text { of tran- } \\
\text { sition }\end{array}$ & No \\
\hline \begin{tabular}{|l|} 
Specific \\
Technol- \\
ogis
\end{tabular} & \begin{tabular}{|c|} 
Infor- \\
mation \\
and Com- \\
munica- \\
tion \\
Technol- \\
ogies
\end{tabular} & $\begin{array}{l}\text { Assistive } \\
\text { social ro- } \\
\text { bots }\end{array}$ & $\begin{array}{c}\text { human re- } \\
\text { sponses to- } \\
\text { healthcare } \\
\text { robots }\end{array}$ & $\begin{array}{c}\text { Assistive } \\
\text { technology in } \\
\text { the care }\end{array}$ & $\begin{array}{l}\text { Com- } \\
\text { puter } \\
\text { based } \\
\text { treat- } \\
\text { ment }\end{array}$ & $\begin{array}{c}\text { Information } \\
\text { and commu- } \\
\text { nication tech- } \\
\text { nologis }\end{array}$ & $\begin{array}{l}\text { Assist- } \\
\text { ing with } \\
\text { medica- } \\
\text { tion ad- } \\
\text { heree }\end{array}$ & \begin{tabular}{|c|} 
Internet- \\
based \\
interven- \\
tions for \\
caregiv- \\
ers deal- \\
ing with \\
assistive \\
technol- \\
ogis
\end{tabular} & $\begin{array}{c}\text { Mobile } \\
\text { health } \\
\text { tech- } \\
\text { nolos } \\
\end{array}$ \\
\hline
\end{tabular}

\subsection{Inclusion and exclusion criteria}

In the next step we narrow down our search to be more specific and to narrow down and evaluated on the basis of following criteria: 
- Articles which were published between 1989 and 2018.

- Articles must utilize a mobile phone as an intervention for their healthcare, involve or directly aim at older people quality of life of 45 years and over.

- Articles must address the question of how mobile services and applications that can be utilized to help improve, what are the barriers to mobile phone use how to overcome these barriers, what are the possible solutions to adopt to smartphones, and how technology can enhance the quality of life.

- Articles must include at least one combination of the search keywords (i.e. target group 1 mobile technology or mobile services and applications).

- Articles must be Scopus publications.

- Using several search keywords and increasing the complexity in the search inclusion criteria improves the quality of the search output.

\subsection{Evaluating the relevance}

In the third step, gathered data were screened for their correspondence to the research questions. Therefore, at the first phase of screening the data, abstracts were reviewed if the articles met the specified inclusion criteria of the present study. Once confirmed, then the full text articles were downloaded for thorough and detailed review. Furthermore, articles which were unclear either to include or exclude from the review process were resolved by discussing with a senior and knowledgeable researcher in the field.

\section{Results and Discussion}

Despite, the fact that the relationship of Assistive Smartphone Application and older adult's cognitive decline is widely explained in the body of the literature in different perspectives, but remains less clear with the mediating aspect of the Assistive Smartphone Health Application in relationship to older adult's cognitive decline(Bharucha et al., 2009) and quality of life(Free et al., 2013; J. Gao \& Koronios, 2010; Lohr et al., 1996; Rosales \& Fernández-Ardèvol, 2016). Hence, there remains minimal attention paid to address connection the mediating role of Assistive mobile health application on the relationship of older adults with cognitive decline and quality of life in the literature.

Previous literature indicates that Assistive Smartphone Health Application does not solely predict the quality of life of older aging, whereas there are many antecedents of Assistive Smartphone Health Application which are explored in the past studies towards successful aging but remains detached (Anderson \& Hussey, 2017). The link between the older adult's cognitive decline, Assistive Smartphone Health Application and quality of life is dynamic in nature (Sun, McLaughlin, \& Cody, 2016) specifically for applications that are associated with diabetes. Consequently, mediation of Assistive Smartphone Health Application in the older adult's cognitive decline and quality of life lacks empirical evidence in the body of knowledge as less attention is paid towards this specific dimension which is the contribution of this study. 
Thus, mediating role of the Assistive Smartphone Health Application in predicting quality of life can be determined altogether with the link of Older Adults with diabetes and Assistive Smartphone Health Application (Desveaux et al., 2018). Therefore, it provides another argument to investigate the mediating direction of Assistive Smartphone Health Application towards predicting quality of life as it is affected by the older adult's cognitive decline but remains minimal in the past literature(Mariam, 2013).Melander-Wikman (2008) and Czaja, (2016) noted that older adult's cognitive decline effects on quality of life is routed through the Assistive Smartphone Application as it serves as the mediating factor between the successful aging and older adult's cognitive decline.

\subsection{Older adult's cognitive decline and assistive smartphone application}

Older adult is the defined as depending on different perspectives and purposes. For example, gerontologists traditionally focus on persons aged 60 years and older. The federal government uses age 65 as a marker for full Social Security and Medicare benefits. Researchers identify subgroups of "older adults" as "younger old" (ages 65-75), "older-old” (ages 75-85), and "oldest old” (ages 85+) (Pérez-Mármol et al., 2016). Older adults experience age-related physical and cognitive changes such as diminishing vision, hearing loss, psychomotor impairment, reduced attention and memory (Young, Koppel, \& Charlton, 2017) which determines that older users will have different requirements and performance from younger adults generations in terms of interaction with technology (Joshi \& Bråthen, 2016; Saare \& Hussain, 2018). Additionally, Plaza et al. (2011) suggested that smartphone apps can help older adults with issues such as safety, security, privacy, and mobility (e.g., person location service, tracking devices, telecare monitoring, and an alarm system). They can include solutions that facilitate older adults' individual development (e.g., distance learning and training) and/or can support services that contribute to older adults' social lives. Such solutions can enable their broad communication with others (e.g., social network and community platforms), hobbies (e.g., digital games adapted for older adults' requirements), or even religion and spirituality (e.g., services offering religious calendars, holy and prayer books, religious ringtones) (Helal et al., 2003). Furthermore, (Petrovčič, Rogelj, \& Dolničar, 2018) examined the acceptance of Assistive Smartphone Application among older adult's cognitive decline, and their results showed that compatibility, effort expectancy, enjoyment, facilitating conditions and social influences significantly affected the older adult's cognitive decline and use of smartphone application (Helal et al., 2003).

Whereas, Assistive Smartphone Application is considered as low perceived usability and low ease of learning for older adult's cognitive decline due to the rather limited level of adaptation of the design of Smartphone Application to their needs (Abdulrazak, Malik, Arab, \& Reid, 2013; Doughty \& Williams, 2016; Piper, Garcia, \& Brewer, 2016).Furthermore, Previous research has reported various elements of Assistive Smartphone Application that are not age-friendly design as they affect older adult's performance while operating smartphone interface (Petrovčič, Rogelj, \& Dolničar, 2017). 
Past research has also suggested that the older adults cognitive decline about the impacts of Assistive Smartphone Application that would increase, maintain, or improve the older adults successful aging (Doughty, 2011; Plaza, MartíN, Martin, \& Medrano, 2011).Furthermore, older adult's cognitive decline leads the Assistive Smartphone Application which indeed affects the quality of life (Plaza et al., 2011). However, Inadequate inquiries have been done in the past to address the relationship of the Assistive Smartphone Application as a driver of quality of lifein result of older adult's cognitive decline (Alsaqer, 2017). Older adult's cognitive decline can be the potential influential factor in the development of the quality of life as it has a direct effect on the Assistive Smartphone Application, but it remained unclear in the past literature as systematic inquiry is needed to understand this mediated relationship.

Therefore, based on the above-mentioned literature, it may be postulated that Assistive Mobile Health Application and older adult's cognitive decline have direct link to define the quality of life of older adults as it remains an uncertain issue in the research. Hence, if the relationship of Assistive Mobile Health Application and the older adult's cognitive decline is positive it would positively affect the quality of life, and vice versa. Thus, we propose the following preposition.

Preposition1: There is a direct positive relationship between older adult's cognitive decline and Assistive Mobile Smartphone Application.

\subsection{Assistive mobile health application and quality of life}

Assistive technology is defined as any device or system that allows an individual to perform a task that they would otherwise be unable to do with increased ease(Curran, 2017; Hussain, Saare, Jasim, \& Mahdi, 2018) in various domains of everyday lives (Holliday et al., 2015) such as medical and public health practices. Hence, support their health and wellbeing (Pinkelman et al., 2016).

mHealth covers a variety of health and wellbeing apps which are designs for selfmanagement of health, wellbeing and long-term conditions and they may or may not be requiring to communicate with a clinician (Holliday et al., 2015). Ventola, (2014) For example, Patients can actively participate in their own care by receiving services to change their health behaviour as application provides the opportunity to access health information and maintain contact with health care professionals (Rocha et al., 2013).These applications are especially useful for monitoring and diagnosing health conditions for those older adults for whom the physicians work far away. Smartphone applications are beneficial as there are variety of applications on fitness, chronic disease management (e.g. diabetes) (Desveaux et al., 2018; Grande \& Sherman, 2018; Husted, Weis, Teilmann, \& Castensøe-Seidenfaden, 2018)

Thus, these facts improve the initiative to examine the mediating role of Assistive Mobile Health Application to explain the relationship with quality of life. Therefore, to explain the said phenomena we propose that:

Preposition2: There is a positive relationship between Assistive Mobile Health Application and quality of life. 


\subsection{Older adult's cognitive decline and quality of life}

There are enough traces in the literature providing evidence to understand and explain the relationship between older adult's cognitive decline and quality of life(Harling, Morris, Manderson, Perkins, \& Berkman, 2017; Tyrovolas et al., 2017; Wallace et al., 2017). In previous studies it is found that older adult's cognitive decline results to have positive quality of life as it positively influence the Assistive Mobile Health Application or vice versa which is evident of the fact that there is a link between older adult's cognitive decline and quality of life(Mariam, 2013; Melander-Wikman, 2008)

Therefore, it may be assumed on the basis of many studies accessible in the previous literature which indicated involvement of certain factors like Assistive Smartphone Application as the predictor or mediator between the link of the older adult's cognitive decline and quality of life but remains detached(Desveaux et al., 2018; Grande \& Sherman, 2018; Husted et al., 2018; Mariam, 2013; Melander-Wikman, 2008)(Slegers, Van Boxtel, \& Jolles, 2008). Based on this, we propose that:

Preposition 3: There is a positive relationship between the older adult's cognitive decline and quality of life.

\section{Conclusion}

In this article the researcher has tried to conceptualize the use of assistive mobile health application to enhance the quality of life of older adults by incorporating some of the central concepts in the older adult's cognitive decline and assistive mobile health application, and it defines these concepts in a way that permits prediction and understanding of quality of life. In combination older adult's cognitive decline and assistive mobile health application, can account for a considerable proportion of variance in quality of life.

\section{$5 \quad$ Future Work}

Although there has been significant research dedicated to the quality of life, however there is certainly still a plethora of opportunities for further studies in this field. It is expected that this article will assist in developing the assistive health applications for older adults keeping in mind their needs. Moreover, it will drag the attention of future researcher to this important area of research and provide researchers with a foundation upon which future knowledge can be built.

\section{References}

[1] Abdulrazak, B., Malik, Y., Arab, F., \& Reid, S. (2013). PhonAge: adapted smartphone for aging population. In International Conference on Smart Homes and Health Telematics (pp. 27-35). Springer. 
Paper-Relationships Between the Older Adult's Cognitive Decline and Quality of Life: The Mediating...

[2] Alsaqer, M. S. (2017). Helping Elderly with Wayfinding \& Physical Exercise: Development of Assistive and Persuasive Mobile Interventions Sensitive to Elderly Cognitive Decline. The Claremont Graduate University. https://doi.org/10.1109/healthcom.2017.8210790

[3] Anderson, G. F., \& Hussey, P. S. (2017). Population aging: a comparison among industrialized countries. Health Affairs.

[4] Anderson, M., \& Perrin, A. (2017). Technology use among seniors. Washington, DC: Pew Research Center for Internet \& Technology.

[5] Apelqvist, J. (2018). The Diabetic Foot Syndrome Today: A Pandemic Uprise. In The Diabetic Foot Syndrome (Vol. 26, pp. 1-18). Karger Publishers. https://doi.org/10.1159/ 000480040

[6] Azir Rezha, N., Maksom, Z., \& Naim, C. P. (2014). Tackling design issues on elderly smartphone interface design using activity centered design approach. ARPN J. Eng. Appl. Sci, 9, 1190-1196.

[7] Bharucha, A. J., Anand, V., Forlizzi, J., Dew, M. A., Reynolds, C. F., Stevens, S., \& Wactlar, H. (2009). Intelligent assistive technology applications to dementia care: current capabilities, limitations, and future challenges. The American Journal of Geriatric Psychiatry, 17(2), 88104. https://doi.org/10.1097/jgp.0b013e318187dde5

[8] Broadbent, E., Stafford, R., \& MacDonald, B. (2009). Acceptance of healthcare robots for the older population: Review and future directions. International Journal of Social Robotics, 1(4), 319. https://doi.org/10.1007/s12369-009-0030-6

[9] Broekens, J., Heerink, M., \& Rosendal, H. (2009). Assistive social robots in elderly care: a review. Gerontechnology, 8(2), 94-103. https://doi.org/10.4017/gt.2009.08.02.002.00

[10] Bujnowska-Fedak, M. M., \& Pirogowicz, I. (2014). Support for e-health services among elderly primary care patients. Telemedicine and E-Health, 20(8), 696-704. https://doi.org/ $10.1089 / \mathrm{tmj} .2013 .0318$

[11] Canada, P. H. A. of. (2014). Seniors' falls in Canada: second report. Public Health Agency of Canada Ottawa, ON, Canada.

[12] Chadwick-Dias, A., Tedesco, D., \& Tullis, T. (2004). Older adults and web usability: is web experience the same as web expertise? In CHI'04 extended abstracts on human factors in computing systems (pp. 1391-1394). ACM. https://doi.org/10.1145/985921.986072

[13] Chin, J., Madison, A., Gao, X., Graumlich, J. F., Conner-Garcia, T., Murray, M. D., Morrow, D. G. (2017). Cognition and health literacy in older adults' recall of self-care information. The Gerontologist, 57(2), 261-268. https://doi.org/10.1093/geront/gnv091

[14] Chou, C.-C., Chang, C.-P., Lee, T.-T., Chou, H., \& Mills, M. E. (2013). Technology acceptance and quality of life of the elderly in a telecare program. CIN: Computers, Informatics, Nursing, 31(7), 335-342. https://doi.org/10.1097/nxn.0b013e318295e5ce

[15] Crouch, E., Probst, J. C., \& Bennett, K. (2017). Rural-urban differences in unpaid caregivers of adults. Rural and Remote Health, 17(4), 4351. https://doi.org/10.22605/rrh4351

[16] Curran, D. (2017). Parents of Autistic Children and Their Experiences With Assistive Technology. Northeastern University.

[17] Czaja, S. J. (2016). Long-term care services and support systems for older adults: The role of technology. American Psychologist, 71(4), 294. https://doi.org/10.1037/a0040258

[18] Czaja, S. J., \& Lee, C. C. (2009). Information technology and older adults. CRC Press.

[19] Desveaux, L., Shaw, J., Saragosa, M., Soobiah, C., Marani, H., Hensel, J., Jeffs, L. (2018). A Mobile App to Improve Self-Management of Individuals With Type 2 Diabetes: Qualitative Realist Evaluation. Journal of Medical Internet Research, 20(3). https://doi. org/10.2196/jmir.8712 
[20] Doughty, K. (2011). SPAs (smart phone applications)-a new form of assistive technology. Journal of Assistive Technologies, 5(2), 88-94. https://doi.org/10.1108/175494511111 $\underline{49296}$

[21] Doughty, K., \& Williams, G. (2016). New models of assessment and prescription of smart assisted living technologies for personalised support of older and disabled people. Journal of Assistive Technologies, 10(1), 39-50. https://doi.org/10.1108/jat-01-2016-0003

[22] Elshourbagy, S. A. M. (2017). Use of Smart Phones to Improve the Human Factors Engineering of People Suffering from Chronic Diseases. In Advances in The Human Side of Service Engineering (pp. 81-91). Springer. https://doi.org/10.1007/978-3-319-41947-3 9

[23] Free, C., Phillips, G., Galli, L., Watson, L., Felix, L., Edwards, P., Haines, A. (2013). The effectiveness of mobile-health technology-based health behaviour change or disease management interventions for health care consumers: a systematic review. PLoS Medicine, 10(1), e1001362. https://doi.org/10.1371/journal.pmed.1001362

[24] Gao, J., \& Koronios, A. (2010). Mobile application development for senior citizens. In PACIS (p. 65).

[25] Gao, Q., Ebert, D., Chen, X., \& Ding, Y. (2015). Design of a mobile social community platform for older Chinese people in urban areas. Human Factors and Ergonomics in Manufacturing \& Service Industries, 25(1), 66-89. https://doi.org/10.1002/hfm.20523

[26] García-Casal, J. A., Loizeau, A., Csipke, E., Franco-Martín, M., Perea-Bartolomé, M. V., \& Orrell, M. (2017). Computer-based cognitive interventions for people living with dementia: a systematic literature review and meta-analysis. Aging \& Mental Health, 21(5), 454- 467. https://doi.org/10.1080/13607863.2015.1132677

[27] Grande, S. W., \& Sherman, L. D. (2018). Too Important to Ignore: Leveraging Digital Technology to Improve Chronic Illness Management Among Black Men. Journal of Medical Internet Research, 20(5), e182. https://doi.org/10.2196/jmir.9434

[28] Grindrod, K., Khan, H., Hengartner, U., Ong, S., Logan, A. G., Vogel, D., ... Yang, J. (2018). Evaluating authentication options for mobile health applications in younger and older adults. PloS One, 13(1), e0189048. https://doi.org/10.1371/journal.pone.0189048

[29] Harling, G., Morris, K. A., Manderson, L., Perkins, J. M., \& Berkman, L. (2017). Social Networks and Social Support among Older Adults in Rural South Africa: Findings from the Health and Aging in Africa: A Longitudinal Study of an INDEPTH Community in South Africa. https://doi.org/10.2139/ssrn.2977867

[30] Helal, S., Giraldo, C., Kaddoura, Y., Lee, C., El Zabadani, H., \& Mann, W. (2003). Smart phone based cognitive assistant. In UbiHealth 2003: The 2nd International Workshop on Ubiquitous Computing for Pervasive Healthcare Applications.

[31] Hinrichsen, G. A., Emery-Tiburcio, E. E., Gooblar, J., \& Molinari, V. A. (2018). Building foundational knowledge competencies in professional geropsychology: Council of Professional Geropsychology Training Programs (Co PGTP) recommendations. Clinical Psychology: Science and Practice, e12236. https://doi.org/10.1111/cpsp.12236

[32] Holliday, N., Ward, G., \& Awang, D. (2016). COCREATING WELLBEING: THE WARMNEIGHBOURHOODS ${ }^{\circledR}$ AROUNDMETM EXPERIENCE. PEER REVIEWED BOOK OF PROCEEDINGS, 177.

[33] Holliday, N., Ward, G., \& Fielden, S. (2015). Understanding younger older consumers' needs in a changing healthcare market - supporting and developing the consumer market for electronic assisted living technologies. International Journal of Consumer Studies, 39(4), 305-315. https://doi.org/10.1111/ijcs.12192

[34] Hu, Y., Eriksén, S., Lundberg, J., Tuvesson, H., Nilsson, L., Fagerström, C., \& Hofflander, M. (2018). Different Ways of Engaging the End-Users in mHealth Services. ETELEMED 2018,110 . 
[35] Hussain, A., Saare, M. A., Jasim, O. M., \& Mahdi, A. A. (2018). A Heuristic Evaluation of Iraq E-Portal. Journal of Telecommunication, Electronic and Computer Engineering (JTEC), 10(1-10), 103-107.

[36] Husted, G. R., Weis, J., Teilmann, G., \& Castensøe-Seidenfaden, P. (2018). Exploring the Influence of a Smartphone App (Young with Diabetes) on Young People's SelfManagement: Qualitative Study. JMIR MHealth and UHealth, 6(2). https://doi.org/10. 2196/mhealth.8876

[37] Jones, M., \& Rowbottom, C. (2010). The role of telecare in overcoming social exclusion in older people. Journal of Assistive Technologies, 4(3), 54-59. https://doi.org/10.5042/jat. 2010.0493

[38] Joshi, S. G., \& Bråthen, H. (2016). SUPPORTING NEW INTERACTIONS WITH PAST EXPERIENCES ANCHORED IN MATERIALS. IADIS-INTERNATIONAL JOURNAL ON COMPUTER SCIENCE AND INFORMATION SYSTEMS, 11(2), 74-89.

[39] Kalimullah, K., \& Sushmitha, D. (2017). Influence of Design Elements in Mobile Applications on User Experience of Elderly People. Procedia Computer Science, 113, 352359. https://doi.org/10.1016/j.procs.2017.08.344

[40] Kuerbis, A., Mulliken, A., Muench, F., Moore, A. A., \& Gardner, D. (2017). Older adults and mobile technology: Factors that enhance and inhibit utilization in the context of behavioral health. https://doi.org/10.31235/osf.io/3qudt

[41] Liu, S., \& Joines, S. (2012). Developing a framework of guiding interface design for older adults. In Proceedings of the Human Factors and Ergonomics Society Annual Meeting (Vol. 56, pp. 1967-1971). SAGE Publications Sage CA: Los Angeles, CA. https://doi.org/ $10.1177 / 1071181312561291$

[42] Lohr, K. N., Aaronson, N. K., Alonso, J., Burnam, M. A., Patrick, D. L., Perrin, E. B., \& Roberts, J. S. (1996). Evaluating quality-of-life and health status instruments: development of scientific review criteria. Clinical Therapeutics, 18(5), 979-992. https://doi.org/10. 1016/s0149-2918(96)80126-3

[43] Mariam, H. (2013). Information and Communication Technologies in Care of ElderlyAddressing Care Assistants' Experiences, Demands and Visions.

[44] McKinnon, N. B., Connelly, D. M., Rice, C. L., Hunter, S. W., \& Doherty, T. J. (2017). Neuromuscular contributions to the age-related reduction in muscle power: mechanisms and potential role of high velocity power training. Ageing Research Reviews, 35, 147-154. https://doi.org/10.1016/j.arr.2016.09.003

[45] Melander-Wikman, A. (2008). Ageing well: mobile ICT as a tool for empowerment of elderly people in home health care and rehabilitation. Luleå tekniska universitet.

[46] Meneilly, G. S., \& Tessier, D. (2001). Diabetes in elderly adults. The Journals of Gerontology Series A: Biological Sciences and Medical Sciences, 56(1), M5-M13. https:// doi.org/10.1093/gerona/56.1.m5

[47] Miller, A. S., Cafazzo, J. A., \& Seto, E. (2016). A game plan: Gamification design principles in mHealth applications for chronic disease management. Health Informatics Journal, 22(2), 184-193. https://doi.org/10.1177/1460458214537511

[48] Moussa, Y., Mahdanian, A. A., Yu, C., Segal, M., Looper, K. J., Vahia, I. V, \& Rej, S. (2017). Mobile Health Technology in Late-Life Mental Illness: A Focused Literature Review. The American Journal of Geriatric Psychiatry. https://doi.org/10.1016/j.jagp. 2017.04.003

[49] Müller, C., Lautenschläger, S., Meyer, G., \& Stephan, A. (2017). Interventions to support people with dementia and their caregivers during the transition from home care to nursing home care: A systematic review. International Journal of Nursing Studies, 71, 139-152. https://doi.org/10.1016/j.ijnurstu.2017.03.013 
[50] Ortman, J. M., Velkoff, V. A., \& Hogan, H. (2014). An aging nation: the older population in the United States. United States Census Bureau, Economics and Statistics Administration, US Department of Commerce. https://doi.org/10.3886/icpsr13577.v1

[51] Pérez-Mármol, J. M., Ortega-Valdivieso, M. A., Cano-Deltell, E. E., Peralta-Ramírez, M. I., García-Ríos, M. C., \& Aguilar-Ferrándiz, M. E. (2016). Influence of upper limb disability, manual dexterity and fine motor skill on general self-efficacy in institutionalized elderly with osteoarthritis. Journal of Hand Therapy, 29(1), 58-65. https://doi.org/10. 1016/j.jht.2015.12.001

[52] Petrovčič, A., Rogelj, A., \& Dolničar, V. (2017). Smart but not adapted enough: Heuristic evaluation of smartphone launchers with an adapted interface and assistive technologies for older adults. Computers in Human Behavior. https://doi.org/10.1016/j.chb.2017.10.021

[53] Petrovčič, A., Rogelj, A., \& Dolničar, V. (2018). Smart but not adapted enough: Heuristic evaluation of smartphone launchers with an adapted interface and assistive technologies for older adults. Computers in Human Behavior, 79, 123-136.https://doi.org/10.1016/j. chb.2017.10.021

[54] Petrovčič, A., Taipale, S., Rogelj, A., \& Dolničar, V. (2018). Design of mobile phones for older adults: An empirical analysis of design guidelines and checklists for feature phones and smartphones. International Journal of Human-Computer Interaction, 34(3), 251-264. https://doi.org/10.1080/10447318.2017.1345142

[55] Pinkelman, A., Roll, M., \& Greene, D. (2016). Use of a Modified Canadian Occupational Performance Measure for Assistive Technology Outcomes in Postsecondary Education. Occupational Therapy in Health Care, 30(4), 388-401. https://doi.org/10.1080/07380577. 2016.1227893

[56] Pinto-Bruno, Á. C., García-Casal, J. A., Csipke, E., Jenaro-Río, C., \& Franco-Martín, M. (2017). ICT-based applications to improve social health and social participation in older adults with dementia. A systematic literature review. Aging \& Mental Health, 21(1), 58-65. https://doi.org/10.1080/13607863.2016.1262818

[57] Piper, A. M., Garcia, R. C., \& Brewer, R. N. (2016). Understanding the Challenges and Opportunities of Smart Mobile Devices among the Oldest Old. International Journal of Mobile Human Computer Interaction (IJMHCI), 8(2), 83-98. https://doi.org/10.4018/ ijmhci.2016040105

[58] Plaza, I., MartíN, L., Martin, S., \& Medrano, C. (2011). Mobile applications in an aging society: Status and trends. Journal of Systems and Software, 84(11), 1977-1988. https://doi.org/10.1016/j.jss.2011.05.035

[59] Poushter, J. (2016). Smartphone ownership and internet usage continues to climb in emerging economies. Pew Research Center, 22.

[60] Rocha, A., Martins, A., Junior, J. C. F., Boulos, M. N. K., Vicente, M. E., Feld, R., ÓLaighin, G. (2013). Innovations in health care services: The CAALYX system. International Journal of Medical Informatics, 82(11), e307-e320.https://doi.org/10.1016/ j.ijmedinf.2011.03.003

[61] Rosales, A., \& Fernández-Ardèvol, M. (2016). Smartphones, apps and older people’s interests: from a generational perspective. In Proceedings of the 18th International Conference on Human-Computer Interaction with Mobile Devices and Services (pp. 491503). ACM. https://doi.org/10.1145/29353334.2935363

[62] Saare, Murtaja Ali; Jasim, Osamah Mohammed; Mahdi, Alia Ahmed; Hussain, A. (2018). Using Big Data in Healthcare Context: a Conceptual Study. International Journal of Engineering \& Technology, 7(20), 882-886. https://doi.org/10.14419/ijet.v7i3.20.28410 
[63] Saare, M. A., \& Hussain, A. (2018). Successful Aging among Older Adults Using Computers: a Systematic Review. International Journal of Engineering \& Technology, 7(20), 50-54. https://doi.org/10.14419/ijet.v7i3.20.18730

[64] Saare, M. A., Ta'a, A. B., Lashari, S. A., \& Sari, S. A. (2018). Mobile System for Managing and Mitigating the Accommodation Problems. In Journal of Physics: Conference Series (Vol. 1019, p. 12045). IOP Publishing. https://doi.org/10.1088/1742-6596/1019/1/012045

[65] Saare, M. A., Ta, A. B., Lashari, S. A., \& Sari, S. A. (2018). Mobile System for Managing and Mitigating the Accommodation Problems.

[66] Slegers, K., Van Boxtel, M. P. J., \& Jolles, J. (2008). Effects of computer training and Internet usage on the well-being and quality of life of older adults: A randomized, controlled study. The Journals of Gerontology Series B: Psychological Sciences and Social Sciences, 63(3), P176-P184. https://doi.org/10.1093/geronb/63.3.p176

[67] Smith, A. (2014). Older adults and technology use. Pew Research Center [Internet \& American Life Project].

[68] Smith, D., Lovell, J., Weller, C., Kennedy, B., Winbolt, M., Young, C., \& Ibrahim, J. (2017). A systematic review of medication non-adherence in persons with dementia or cognitive impairment. PloS One, 12(2), e0170651. https://doi.org/10.1371/journal.pone.0170651

[69] Stellefson, M., Paige, S. R., Tennant, B., Alber, J. M., Chaney, B. H., Chaney, D., \& Grossman, S. (2017). Reliability and Validity of the Telephone-Based eHealth Literacy Scale Among Older Adults: Cross-Sectional Survey. Journal of Medical Internet Research, 19(10). https://doi.org/10.2196/jmir.8481

[70] Sun, Y., McLaughlin, M. L., \& Cody, M. J. (2016). Using the Smartphone to Support Successful Aging: Technology Acceptance with Selective Optimization and Compensation Among Older Adults. In International Conference on Human Aspects of IT for the Aged Population (pp. 490-500). Springer. https://doi.org/10.1007/978-3-319-39943-0 47

[71] Thilo, F. J., Bilger, S., Halfens, R. J. G., Schols, J. M. G. A., \& Hahn, S. (2017). involvement of the end user: exploration of older people's needs and preferences for a wearable fall detection device-a qualitative descriptive study. Patient Preference and Adherence, 11, 11. https://doi.org/10.2147/ppa.s119177

[72] Thow, M. E., Summers, M. J., Saunders, N. L., Summers, J. J., Ritchie, K., \& Vickers, J. C. (2018). Further education improves cognitive reserve and triggers improvement in selective cognitive functions in older adults: The Tasmanian Healthy Brain Project. Alzheimer's \& Dementia: Diagnosis, Assessment \& Disease Monitoring, 10, 22-30. https: //doi.org/10.1016/j.dadm.2017.08.004

[73] Tsai, H. S., Shillair, R., \& Cotten, S. R. (2017). Social Support and "Playing Around" An Examination of How Older Adults Acquire Digital Literacy With Tablet Computers. Journal of Applied Gerontology, 36(1), 29-55. https://doi.org/10.1177/0733464815609440

[74] Tyrovolas, S., Polychronopoulos, E., Morena, M., Mariolis, A., Piscopo, S., Valacchi, G., Tyrovola, D. (2017). Is car use related with successful aging of older adults? Results from the multinational Mediterranean islands study. Annals of Epidemiology, 27(3), 225-229. https://doi.org/10.1016/j.annepidem.2016.12.006

[75] Ventola, C. L. (2014). Mobile devices and apps for health care professionals: uses and benefits. Pharmacy and Therapeutics, 39(5), 356.

[76] Wallace, L. M. K., Ferrara, M., Brothers, T. D., Garlassi, S., Kirkland, S. A., Theou, O., ... Rockwood, K. (2017). Lower frailty is associated with successful cognitive aging among older adults with HIV. AIDS Research and Human Retroviruses, 33(2), 157-163. https://doi.org/10.1089/aid.2016.0189 
[77] Young, K. L., Koppel, S., \& Charlton, J. L. (2016). Toward best practice in human machine interface design for older drivers: a review of current design guidelines. Accident Analysis \& Prevention. https://doi.org/10.1016/j.aap.2016.06.010

[78] Young, K. L., Koppel, S., \& Charlton, J. L. (2017). Toward best practice in human machine interface design for older drivers: a review of current design guidelines. Accident Analysis \& Prevention, 106, 460-467. https://doi.org/10.1016/j.aap.2016.06.010

[79] Zwijsen, S. A., Niemeijer, A. R., \& Hertogh, C. M. P. M. (2011). Ethics of using assistive technology in the care for community-dwelling elderly people: An overview of the literature. Aging \& Mental Health, 15(4), 419-427. https://doi.org/10.1080/13607863.2010.543662

\section{$7 \quad$ Authors}

Murtaja Ali Saare is a Ph.D. student at School of Computing, Sintok, Universiti Utara Malaysia, Kedah, Malaysia. He holds a master's degree in computer science. His research interests include aging and cognition, e-health, and human-computer interaction. He has published his work in reputable Scopus indexed journals.

Azham Hussain is the Associate Professor of Software Engineering at School of Computing, Universiti Utara Malaysia, Kedah, Malaysia. He is the founder of HumanCentered Computing Research Group, which is affiliated with the Software Technology Research Platform Center at School of Computing, Universiti Utara Malaysia. Azham Hussain is a member of the US-based Institute of Electrical and Electronic Engineers (IEEE), and actively involved in both IEEE Communications and IEEE Computer societies.

Dr Wong Seng Yue is a senior lecturer at the Centre for the Initiation of Talent \& Industrial Training, Universiti Malaya, Kuala Lumpur, Malaysia. He received PhD degree in information science. He current researches include mobile augmented reality in STEM, gamification and e-health with industry 4.0 .

Article submitted 2019-07-11. Resubmitted 2019-08-16. Final acceptance 2019-08-22. Final version published as submitted by the authors. 